前立腺癌および肥大症のホルモン依存性に ついての酵素学的研究

\author{
東京医科碀科大学医学部泌尿器科教室 \\ (主任 : 落合京一郎教授) \\ 竹内弘幸

\section{ENZYMOLOGICAL STUDY ON THE HORMONE-DEPENDENCY OF THE PROSTATIC CANCER AND PROSTATIC HYPERTROPHY}

\author{
Hiroyuki Takeuchi \\ Department of Urology (Director: Prof. K. Ochiai), \\ Tokyo Medical and Dental University, Tokyo
}

It is already known the structure and the functions of the prostate are controled by androgens. Also the growth of prostatic cancer, which is characterized by their automatic growth, depends on androgens like the normal prostate, and, on the utilization of this biological character, hormone therapy of prostatic cancer, that is to say anti-androgenic therapy, has been developed. Some pathological and biochemical results supporting effectiveness of the hormone treatment are seen in literature. But it is rather hard to find any literature in which the hormone-dependency of prostatic cancer is investigated on the cancerous tissue itself by biochemically quantitative way.

The first purpose of author's investigation is to pursue the problem of the hormone-dependency of prostatic cancer quantitatively by measuring some enzymatic activities contained in the cancerous tissue.

On the other hand, benign prostatic hypertrophy and prostatic cancer strikingly contrast each other in many points. One of the most noticeable differences in clinical findings of both diseases is the fact that the growth of prostatic cancer can be controled with hormone treatment, whereas in prostatic hypertrophy the hormone-dependency in the same significance is scarcely demonstrated. The second purpose of this investigation is to compare these differences biochemically and enzymologically.

\title{
Methods
}

Acid phosphatase and protease which are belived to be characteristic of the prostate were chosen as the indicators of this investigation. These enzymatic activities in prostatic tissue were measured, and then, their rise and fall after hormonal treatment were pursued in this present study.

The estimation of these enzymes was done with fresh specimens obtained actually at operation. Patients from whom prostatic tissue wes removed consist of 39 cases of prostatic adenoma, 20 cases of postatic cancer and 4 cases of normal prostate. Among them, in 22 cases of prostatic hypertrophy and 11 cases of prostatic cancer a synthetic estrogen (hexestrol) was administered or orchiectomy was performed before removal of the prostatic tumor. After the removed prostatic tissue was homogenized, the extract with physiologic saline solution was prepared, was diluted 1:50,000, and each enzyme was estimated per gram fresh tissue.

Acid phosphatase was determined by the metod of Hudson. The activity was expressed by the amount of p-nitrophenol liberated from p-nitrophenylphosphate by enzymatic reaction of the tissue extract. Protease was determined by the casein-Folin method described by Hagiwara. The activity was expressed by the amount of the portion that remained dissolvable when protein-precipitant was. added to the products liberated from casein by the tissue extract.

\section{Results}

The results of the study are summarized as follows.

(1) Normal prostatic tissue contained almost the same amount of acid phosphatase per gram fresh tissue.

(2) The adenomatous tissue generally contained apparently much more acid phosphatase than the normal tissue. Individually, however, slight differences were recognized, and the were considered to be related to histological appearance. Those that had well developed grandular structure contained more acid fphosphatase than less developed. The more portion was occupied by the 
interstitial tissue, the less amount of acid phosphatase was contained. The amount of acid phosphatase contained in the adenomatous tissue hardly decreased in so far as the treatment with $300 \mathrm{mg}$. of hexestrol, and histomorphólogic changes were also not recognized.

(3) The cancerous tissue showed significant difference of the enzyme amount whether histologically well differentiated or less differentiated, and contained mostly as much acid phosphatase as the adenomatous tissue; both tissues showed higher lebel than the normal tissue. The cancerous tissue after hexestrol administration or orchiectomy showed a remarkable decrease of the acid phosphatase content, and the significant inhibition of the enzyme production in the prostatic cancer was confirmed after the administration of hexestrol above $100 \mathrm{mg}$. Histologic changes caused by estrogen were found in some cases, but were very slight.

From the fact that the production of acid phosphatase in the prostate is intimately related with androgen secretion, abundant content of the enzyme in prostatic hypertrophy as well as in prostatic cancer shows that both prostatic tumors are androgen-dependent. But the responses of anti-androgenic treatment are remarkably different; whereas in the prostatic cancer the phosphatase activity can be distinctly inhibited by the treatment before the morphologic changes appear, in the prostatic hypertrophy the enzyme activity is scarcely influenced. Though such a difference remains to be clarified, author's enzymological investigation demonstrates that the prostatic cancer is the androgendependent tumor in strict sense.

(4) Though the quantity of protease in prostatic tissue was considerably different in individnal cases, it might be said in general that normal prostate, adenomatous prostate and cancerous prostate contained nearly similar amount of protease. After hexestrol administration the normal prostatic tissue, adenomatous and cancerous tissues showed less amount of protease than the one treated with estrogen, and the rate of decrease in the cancerous tissue was more noticeable.

(5) Allane phosphatase in prostatic tissue could not be detected. In other words, alkaline phosphatase level in prostatic tissue can be thought to be very low, compared with acid phosphatase.

\section{I. 緒 言}

周知のように, 前立腺癌泳ルルモン依存性(hormonedependent)の悪性腫㻛の代表的なものである. この前立 腺癌がホルモンとくに，男性ホルモンに依存するという こと泳，主としていわりる抗男性ホルモン療法によつて この癌の発育をコントロールできるという Huggins ら （1941）の経験的事実に基くといえるわけであるが，も ちろんとれと平行しててのホルモン依存性は病理組織学 的，あるいは間接ではあるが血清中のphosphatase の消 長なぞの生化学的研究によつても一応㤝裹づけされてい る.ところが，乙れとは発生母地を異にするとはいえ， 同じ前立腺という缄器から発生する前立腺肥大症に於て は，乙の抗男性ホルモン療法というものが殆しど効果を 来たさないしとが経験的諗められている.いいかえる と自律性 (autonomous) 発育というととを特致とする 悪性腫瘍である前立腺癌がホルモンによつてコントロー ルされるのに，あくまで良性腫湯としての性状をもつ前 立腺肥大症の方がかえつてホルモン依存性を示さないと いう奇妙な対照を示している. 前立腺腫瘍付けるホル モン依存性の問題が提起されてすでに20年余りになる が, ての点についての詳しい研究追求はまだ全く行なわ れていない。

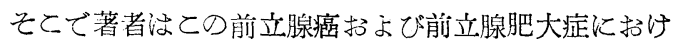
るホルモン依存性のちがい, また前立腺癌のホルモン依 存性己いわする抗男性ホルモン（発情物質投与あるいは 涂罯術）によるコントロールの消長というととに重点を お点, 前立腺汇特有とされるphosphatase(とく汇酸 pho- sphatase) 扮よび前立腺腫瘍と関連む゙染いともいわれて いるproteaseの前立腺組織内の含有量を測定するとと汇 よつて,生化学的な面から袷索比較を行つたものである.

\section{II. 検索材料と検索方法}

緒言で述べたように，前立腺組織内に含有される P-a se (とくに酸 P-ase), 前立腺機能との関連が深、と推定 されている proteaseを示標とし各種ホルモン療法 (estrogens投与あるいは両側睪丸剔除術）を行つた場合の前 立腺腫湯組織について，乙れら醭素を測定しその活性度 の消長亦らホルモン依存性というととを生化学的に追求 したものである.

\section{(A) 湘定に供した前立腺組織}

これら酶素の測定に用いたものはいずれも著者の泌尿 器科教室に执いて手術的に採取した前立腺腺腫, 前立腺 癌晾よび正常前立腺組織である.

前立腺腺腫 39 例（第 2 表, 第 3 表）：前立腺肥大症と して腺腫剔除術を行つたもので, このうち17例は手術前 に estrogens 投与を行つたもの，22例汸手術前に estrogensを投与してから（投与量捛よび投与期間については 第 3 表の検索成績を参照）腺腫剔除を施行したもの.

前立腺癌 20 例(第 4 表, 第 5 表, 第 6 表) : 大部分は経尿 道的あるいは経膀胱的に組織を採取したものであり. 1 例だけ忍比輘的早期の癌で根治的前立腺剔除術によるも のである. てのうち9例は組織切除前汇何らのホルモン 療法をも行わなかつたもの，9例は予め estrogens を 投与してから，2 2 例は去勢術を行つてから組織を切除し たものである，醳素活性度測定に洨後述するょう最少 
量 4〜5 g 学必要とするわけで前立腺癌においてはいず れもこれを最少量としてそれ以上の癌組織を採取してい る.

正常前立腺 4 例（第 1 表）：こ元は前立腺腫場の対照 としたもので, 膀胱腫晹のために膀胱全剔除を行つたも のあるい湔立腺結石手術（前立腺切石術）の際汇藏器 組織の一部を採取したものである(第 1 表参照).

以上のようにして採取した前立腺組織の一部分は病理 組織学的検查に供し, 残りの組織部分については次のよ ろな方法で醳素活性度を測定した。

(B) 前立腺組織内の醭素測定方法

(1) 前立腺組織抽出液の作成

手術的に切除採取した前立腺組織を隇菌水で沙つてで

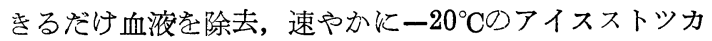
一内で凍結させる. 完全に凍結したところでその $5 \mathrm{~g}$ を 科量切除し, これ学カミソリで削つて薄片とする.これに 生理食塩水 $20 \mathrm{cc}$ 加えて元にもどし，ニニバーサル・ホ モジナイザー(日本精器製作所製のHA型，無負荷 20,000 r.p.m.）江 5 分間忍汀て完全に乳化させる. 1 時間放置 抽出を行つてから高速遠心沈䬺機 (久保田製作所製, KCF 62型）て10,000〜1,2000G，20分間の遠心分離を行う.

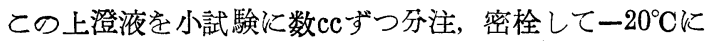
凍結する. これらの操作はすべて $4{ }^{\circ} \mathrm{C}$ 以下にて行う.

このょうにして凍結保存された前立腺組織抽出液は醭 素測定に先だつてまず室温で自然に融解させる。（一度 融解した検体注再使用しない).Proteaseの活性度測定に はこの溶液をこのま>使用しP-ase の活性度測定には 4 ${ }^{\circ} \mathrm{C}$ 泠却した生理食塩水で 10,000 倍に稀釈しをものを供 する.

(2) P-ase (酸掞よびアルカリP-ase) の測定 いわゆる総数 P-ase (total acid phosphatase) の測 定には p-nitrophenyl-phosphateを基質とする BesseyLowry 法 (1946) の Hudson らの変法 (1947), いわ 方前立腺性酸 P-ase (prostatic acid phosphatase) の测定に汸醭素活性抑制のため1-tartrate を用いる Fishman Lerner 法 (1953) 应用, 乙れを加えた被 検液について Hudson らの方法で酸 P-ase を測定し たわけである、アルカリP-ase は Bessey-Lowry 法に よつた. 測定法の大略は次のようである (金井, 1960 ; 落合, 1963 ; 竹内, 1964などを参照).

P-ase 活性の単位标, 実際に使用に供した前記り稀 釈液によつて得られた測定值をむつて表現してある (Bessey-Lawry 単位は 元来, 被㭘液 $11 か ゙ 37^{\circ} \mathrm{C} 1$ 時間 p-nitro-phenyl-phosphate に作用して遊離する p-nitrophenol Ð mM 数で定義する). $1 \mathrm{~g}$ 前前腺組織が 含有するP-ase, 注 p-nitrophenyl-phasphate $に 37^{\circ} \mathrm{C} 1$ 時間作用させた場合, ここ汇表現された活性度の50倍の
数値に相当する $\mathrm{mM}$ 数の p-nitrophenol を遊離する能 力をもつている. したがつて $1 \mathrm{cc}$ 血清に比較した場 合, $1 \mathrm{~g}$ の前立腺組織は大よそその 50,000 倍のフォスフ アターぜ活性を示していることになる.

著者が実施した P-ase 測定法

（i）アルカリP-ase 測定用緩衝液: $0.1 \mathrm{M}$-glycine, $0.001 \mathrm{M}-\mathrm{Mg} \mathrm{Cl}_{2}$ 妾含む混液で $\mathrm{pH} / 210.5$ 亿調製する。

(ii ) 総酸 P-ase 測定用緩㣫液 : 0.09M-citrate 0.18 $\mathrm{M}-\mathrm{NaOH}, 0.01 \mathrm{M}-\mathrm{HCl}$ を含む混液で, $\mathrm{pH}$ は 4.8 亿調製 する.

(iii) 前立腺性酸p-ase測定用緩衝液 : 上記総酸 P-ase 測定用緩衝液にl-tartrate $0.04 \mathrm{M} の$ 濃度に加えたもの で, pHは 4.8亿調整する.

（iv）基質原液: Disodium p-nitrophenyl phasphate $100 \mathrm{mg}$ 水 $25^{\circ} \mathrm{C}$ 亿溶解する。

(v) 標準曲線：0.05mM-p-nitrophenol 溶液を標準 液乞し，ての溶液 $1 \mathrm{cc} 11.1 \mathrm{cc}$ に稀釈したものが示す吸 光度 (波長 $420 \mathrm{~m} \mu$ ) をアルカリ P-ase 活性の 1 単位, 酸 P-ase の 0.234単位さする. 標準液 $1 \mathrm{cc} \sim 10 \mathrm{cc}$ の系列 について測定した数值をグラフ上に描記したものを標準 曲線として使用さる。

（vi）アルカリP-ase の測定法 : 基質液之緩衝液の $\mathrm{pH}$ 10.5 亿調整した等量混和液 $1 \mathrm{cc}$ を $37^{\circ} \mathrm{C}$ 恒温槽で定温とし, 検体 $0.1 \mathrm{cc}$ を加え 30 分間作用させをあと， $0.02 \mathrm{~N}-\mathrm{NaOH}$ $10 \mathrm{cc}$ 加えて呈色させ，醭素液のかわりに水 $0.1 \mathrm{cc}$ を用いて 上記と同梯の操作をしたものを対照としてその吸光度学 求める. 次に両試駼管汇濃 $\mathrm{HCl} 2$ 滴を加えて p-nitrophenol の色を消し，検体乞のものの吸光度を測定する。 検体が作用して呈色した p-nitrophenol の吸光度から㭘 体そのものの吸光度を差引いた数值から標準曲線を用い て検体の䤃素活性を定める.

（vii）総酸 P-ase 測定法 : 基質原液之総酸 P-ase 測 定用緩衝液のpH 4.8 亿調整した等量混和液 $1 \mathrm{cc} 37^{\circ} \mathrm{C} の$ 恒温槽で定温とし， $0.2 \mathrm{cc}$ 検体学加え 30 分間作用させ たあと， $0.1 \mathrm{~N}-\mathrm{NaOH} 4 \mathrm{cc}$ を加えp-nitrophenol 発色さ せる. 検体のかすりに水 $0.2 \mathrm{cc}$ 加えて上記て同様の操 作をしたものを対照亡して吸光度を求める. 別に検体盲 検として検体 $0.2 \mathrm{cc}$ に $0.1 \mathrm{~N}-\mathrm{NaOH} 5 \mathrm{cc}$ 加えたもの の吸光度を $0.1 \mathrm{~N}-\mathrm{NaOH}$ を対照として求める。㛟体を 作用させたものの吸光度から盲検の吸光度を差引いた数 值から標準曲線を用いて䤃素活性を定める。

（viii）前立腺性酸P-aseの測定法 : 総酸 P-aseの測定 法と異なるこころは, 総酸P-ase 測定用緩衝液のかわり に 1-tartrate を加えた緩衝液を用いる点である. 前立 腺性酸 P-aseの活性度は総酸 P-aseの活性度心らl-tartrate を加えた緩衝液使用の酸 P-ase の活性度を差引い たものである. 
酸P-ase について何故にてのような測定法によつたか は，P-ase 酸の測定には一つの問題があるからである. 前立腺が他の歲器組織とは桁はずれに多い酸 P-aseを生 成分泌するもので, 男子血清中に含まれる酸P-aseの大部 分泣前立腺に由来放え考えてょいが，一部分は肝，骨， 腎などにす由来する酸 P-aseである，また赤血球中にも かなり多量の酸 P-ase态含まれている。この血清中の酸 P-ase はこの意味で一般に総酸P-ase (total acid phosphatase）とよ注れ前立腺に由来する酸 P-ase（前立腺 性酸 P-ase, prostatic acid paosphatase) と区別されて いる.一般に行われている血清の酸 P-ase測定法はこの 総酸 P-aseの活性度を測定しているものであるが，前立 腺腫瘍の場合にはこの前立腺性酸P-ase だけを測定する 方法が望ましい，てのために，前立腺性酸P-aseだけをで きるだけ特異的に測定しょうこいろいろな測定法が考察 発表されている。 たとえ洼 ethyl alcohol法 (Herbert, 1946), farmaldehyde法 (Abdul-Fadl, 1949),1-tartrate 法 (Fishman-Lerner, 1953) などである。とのうちて は, 1-tartrate で前立腺性酸 P-ase活性を抑制する Fishman-Lerner 法が臨床的には賞用されている（松村， 1959 ; 紼, 1959 ; 竹内, 1964など).

これは血清についての測定の場合のことで, 前立腺組 織そのものについての酸 P-ase 測定なら, 総酸P-ase 前立腺性酸 P-ase とをとく汇区別する必要はないうけで ある.しかし,採取した前立腺組織はできるだけ完全に残 存する血液を洗い落してはいるが, 組織内部のものまで 完全に除去するわけにはいかないとともある. またホモ ジナイザーにかけて抽出液を遠心分離しても，でく少量 残存しているかもしれない赤血球が崩壊して, その含有 する酸 P-ase がこの前立腺組織抽出液中に流人している

第 1 圀 赤血球性 P-ase に対する p-nitrophenyl-phosphate 法の感受性

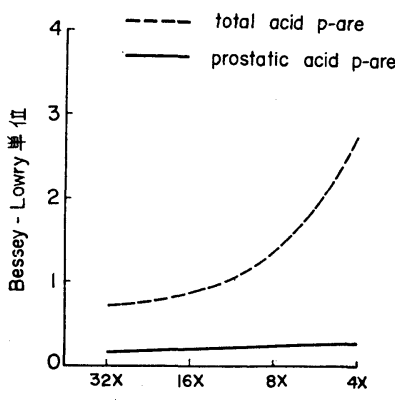

溶血赤血球の稀釈倍数
こともあり，総酸 P-ase の測定では必ずしも前立腺性 酸P-ase だけを測定していると沈断言できない。そこで 著者はつぎのような予備実験文行なつた。

(3) 前立腺組織についての酸 P-ase測定法の予備実 験

まず前立腺組織の抽出液（作製については第 2 節を参 照), 血液より赤血球を分離洗滌して溶血させた液さいう 2 種類の被検体をつくる.それぞれの被検体をWoodard (1951) の方法で不活性化 した保存血清で倍数稀釈す る. 各稀釈液について総酸P-ase (Hudson法) および前 立腺性酸 P-ase (Fishman-Lerner 変法) の活性度を測 定した. その成績汇第 1 区捛よび第 2 四の如くである.

醭素(溶血赤血球液, 前立腺組織抽出液)を加えない不 活性化血清のみの酸P-ase活性度恃 0 である. 総酸P-ase 去血球性 P-ase 汇強く反応するが, 前立腺性酸 P-ase ち即 1-tartrate により抑制されている酸 P-ase 分畫は かなりの低值を示し, 各稀釈度に於て総酸 P-ase 中に しめる割合㳉 $20 \%$ 程度である (第 1 図).しかるに前立腺 組織抽出液に対しては総酸 P-ase と前立腺性酸 P-ase はほざ一致した值を示し，各稀釈度に於て後者の前者に 対する割合は $80 \%$ 程度である (第 2 図).換言すれば，前 立腺組織抽出液の中には 1-tartrateにより抑制されない 酸 P-ase 分畫は殆んど含まれず，高ふ20\%程度であるこ とがす心る. しかも試料中には混在する赤血球に由来す る酸 P-aseが含まれている可能性もあるから，実際には 更に低い值を示すむのと考穴られる。一方赤血球中の酸 P-ase は,クエン酸だけの緩衝液と 1-tartrateを加えた 緩衝液とを用いた測定て殆え ご同様の測定值る示すが, 1-tartrate により抑制される酸 P-ase 分畫は20\%程度に 汢存在する。したがつて前立腺組織抽出液であ検体によ

第 2 図 前立腺性 P-ase に対する p-nitrophenyl-phosphate 法の感受性

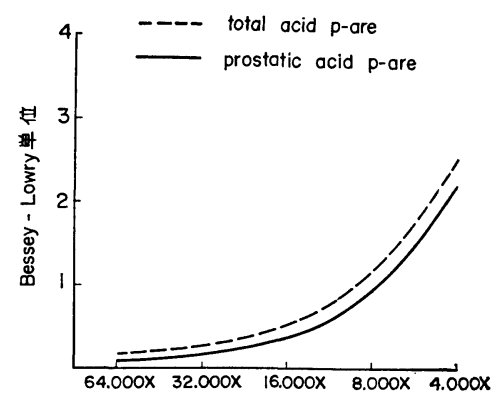

前立腺組噼抽出液の稀规倍数 
つて溶血量が異るから, 総酸 P-ase酸と同時に前立腺性 酸 P-aseを測定しなければ相互の比較々゙不正確となる.

本測定法の前立腺性酸 P-aseに対する感受性の赤血球 性 P-ase との相対的な特異性を数字で表わすのに，総酸 P-ase值が同值を示す時の両者にみられる1-tartrateに抑 制される分畫の割合の比を採用すると，本節の予備実験 に供された検体では, 種くの総酸 P-ase 值について大 凡その比は 4 である。したがつて本測定法は, 前立腺 性酸 P-ase に対し赤血球性酸 P-ase に対するょり 4 倍 高い感受性を示すと言える。しかし実際に我々が前立 腺組織について測定学行な弓時の溶血量沙極好低いか ら，更に高い特異性をもつているものと考えられる。

実際にも前立腺組織について著者がその酸 P-ase活性 度を測定したこころでは, Hudson 法とFishman-Lerner 法とでは多くの場合に同じ測定值を示していた. しかし， 上述のょうに完全に赤血球由来の酸P-ase の混在を除去 できないという点孝考慮し, 必ず両者の測定法を行なつ た。ただし以下に挙げた酸 P-ase值はいずれもFishman-Lerner 法による前立腺性酸 P-aseの值定值である.

（4）アルカリ P-ase の測定

酸 P-ase測定と同時に、同じ被検体について上述した ような方法でアルカリ P-aseをも測定した (Bessey-Lowry 法).

(5) Protease の測定

後章でも述べるうに, 前立腺組織内のいわゆる蛋白

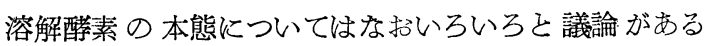
が，著者は一応これを Protease として測定したもので ある。

P-ase 測定に使用したと同じ前立腺組織抽出液の別の サンプルについて, その含有する Protease を測定した. Proteaseつ測定法としては萩原 (1961) のCasein-Folin 呈色法を応用した。 すなわち, 䤃素を含有する被検液, この場合牥稀䣋した前立腺組織抽出液をまずCaseinに作 用させてから，除蛋白剮を加え，乙の非沈澱性分解物を Folin 試薬で発色させて，乙れを光電比色計で測定する 方法である.ただし原法では 1 分間に tyrosine $1.0 \gamma$ 相 当量のFolin 呈色を示す非蛋白性物質を生成する如き醉 素活性を 1.0 単位こするが，著者は標準protease 1.0 r と同じ力価を示す実際に使用する稀釈された前立腺組織 抽出液の醭素活性を 1.0 単位已定めた。乙れ认よる単位 は, tyrosine 単位の約 1.4倍を示す. 又前立腺組織 $1 \mathrm{~g}$ の有する casein 溶解能は, 表現された測定値の5 倍值 に埋当する $\gamma$ 数の標準 Protease と同価である.

著者の行つた protease 測定法
（i）基質溶液：Casein (Merck社製） $1.2 \mathrm{~g}$ を0.05 $\mathrm{M}-\mathrm{Na}_{2} \mathrm{HPO}_{4} 160 \mathrm{cck}$ 加温溶解し $\mathrm{pH}$ 7.5 調整したの 与, 水で $200 \mathrm{cc}$ に稀积する.

(ii) 除蛋白液 : $0.11 \mathrm{M}-\mathrm{CCl}_{3} \mathrm{COOH}, 0.22 \mathrm{M}-\mathrm{CH}_{3} \mathrm{C}-$ $\mathrm{OONa}$ 抢よび0.33M- $\mathrm{CH}_{3} \mathrm{COOH}$ を含む混液.

(iii) Folin呈色用緩衝液 : $0.55 \mathrm{M}-\mathrm{Na}_{2} \mathrm{CO}_{3}$.

(iv) Folin 試薬：1.51〜210 丸底フラスコに約 $700 \mathrm{cc}$ 水安入礼 $\mathrm{Na}_{2} \mathrm{Wo}_{4} \cdot 2 \mathrm{H}_{2} \mathrm{O} 100 \mathrm{~g}, \mathrm{Na}_{2} \mathrm{M}_{0} \mathrm{O}_{4} \cdot 2 \mathrm{H}_{2}$

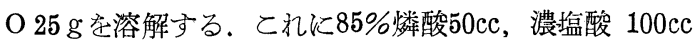
を添加する。フラスコにゴムまたはコルク栓で還流冷却 器をつけ穏かに沸騰させる。. 1 2 時間以内に濃緑色に たるが10時間沸騰をつぶける，液は殆んぞ透明な筈であ る. 終了後直ちに $\mathrm{LiSO}_{4} 150 \mathrm{~g}$, 水約50ccを加光, 脱 色のために液体臭素 $1 \sim 2$ 滴を添加してから椧却器を外 して沸騰させる. 脱色後液が完全に黄色になつたら, 過 剩の具素を追出すために，15分間緑色に復色しないょう に穞かに沸騰学つぶける. との液を冷却後水で全容を 1 1 となしてからグラスフイルターで滤過する，密栓して して保存する。

(v) 標準曲線 : 市販の Protease (Nutritional Biochemicals Corporation） $1 \mathrm{r} / \mathrm{cc}$ 分基質溶液に作用して 産生される非沈溉分解物が示す Folin 呈色量学 1 単位己 する. 標準 protease $0 \sim 20 \mathrm{r} / \mathrm{cc}$ の間で濃度の異る系列 を作り，この溶液で下記測定法によつて得られた測定值 をそれぞれ 0〜20単位に対応してグラフ上に描記しもの を標準曲線とする。

（vi） Protease の測定： $5 \mathrm{cc}$ の基質溶液を $30^{\circ} \mathrm{C}$ 恒 温槽で定温とし, 醭素液 $1 \mathrm{cc}$ 加えて 10 分間作用させ る. 10 分後除蛋白液 $5 \mathrm{cc}$ を加えて恒温槽中に 30 分間放置 した後硬質滤紙で滤過する。滤液 2 ccに0.55M- $\mathrm{Na}_{2} \mathrm{CO}_{3}$

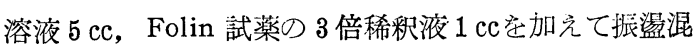
和し, $30^{\circ} \mathrm{C}$ 恒温槽に 30 分放置する. 呈色を示した試料は $660 \mathrm{~m} \mu$ で吸光度を測定する。

対照には醳素液に除蛋白液导加え, 10分間放置後基質 液を加えたものを $30^{\circ} \mathrm{C} て ゙ 30$ 分間放置したものを上記の要 領で Folin 呈色させる.

測定試料の吸光度から対照の吸光度を差引い 数值か ら標準曲線を用いて検体の醭素単位を定める。

(6) 前立腺組織の病理組織学的検索

P-ase 招よび protease の含有量を測定した前立腺腫 瘍については, すべてその一部で病理組織学的検査学行 い, 前立腺肥大症あるい前立腺癌であること学組織学 的汇確認した (中央検查室病理学部).また前立腺腫およ 
び前立腺癌については，その組織像からてれを次のょう に分類した。

(a) 前立腺肥大症の病理組織学的分類

前立腺肥大症 (腺腫) の組織については，主として 左右あるいは中葉のいずれかを横断して組織標本を作製 し，てれについて腺構造が間質に対して占める割合から これを以上のような 3 型に分類した。

第 1 型 : 全視野を通じて腺葉招よび管腔構造の部分が 間質に対し大よそ $2 / 3$ 以上を占めているもの.

第 2 型 : 第 1 型よりは腺管構造の部分がや >少いも の.

第 3 型：腺管構造部分よりは間質組織の方が多いも ๑.

(b) 前立腺癌の病理組織学的分類

前立腺癌の病理組織分類についてはいくつかの提案が あるが，著者は一応 Shelleyら (1958) の分類に淮じて これを 2 型に分けた. Shelley らはもともと腺管構造と 癌細胞の分化の程度によつててれを 4 型に分けている が、実際にはこの細かい分類は必ずしも容易ではない。 ことにホルモン療法施行後の切除組織では，乙のような 分け方が困難というょりも不正確になりやすいからで， この点を考慮して著者はこれを次の 2 型に分けた。

第 1 型 : 癌細胞の分化の程度犬゙比較的高く腺管構造も よく発達しており，管腔内には分泌物がかなり多量に含 まれているもの，てれよりもや〉分化の程度は低く腺管 構造はある程度までつくられているが管胿内容は比較的 そしいもので，いずれにしても，形態的にはつきり腺癌 と判定し得るもの含めてある.だ゙ての後者の型は後 述するように，ある程度の量の estrogens を投与された 前立腺癌には時に見られる構造ともいえる。

第 2 型 : 大小不同の集団をつくつた癌細胞巣が浸潤性 に間質内に存在し，乙の癌細胞集団のところどころにわ ずかながら腺構造の存在が認められるもの，あるい殁 んぞ腺構造を示していない未分化の細胞集団からなるも のを含めた．いわび前立腺の未分化癌か，それに近いも のを第 2 型してと分けた。

\section{III. 検索成績}

前章で述べたょうに，組織内の各醳素を測定した材料 以正常前立腺 4 例, 前立腺肥大症 39 例怙よび前立腺癌 20 例の計63例である．その測定成績のうち訳法次のと就り である.

(A) 酸 P-aseの測定成績

（a） 正常前立腺組織内の酸 P-ase ( 4 例, 第 1 表).
ことにいう正常前立腺とは前立腺肥大症よおび癌以外 の前立腺組織という意味である. 全く正常な前立腺か ら，醰素測定が可能なだけの組織を採取するととは実際 上不可能孞からであある. したがつて第 1 表に示すよう に, 3 例の膀胱腫瘍で膀胱全剔除術を行つたもののうち の1例は病理組織学的には小さいながら腫瘍の形成を認 めたものがある．また前立腺結石症例では慢性の前立腺 炎を伴つていたが，腺構造に注著しい变化はなかつたも のである.

これら前立腺組織内の測定値について見ると，前立腺 肥大症执よび癌以外のいわば正常かそれに近い中年者あ るい放それ以後の前立腺組織 $1 \mathrm{~g}$ 当りの酸 P-ase活性度 は0.16〜0.34単位る示していた.ただ 3 例では0.16〜

第 1 表 肥大症, 癌以外の前立腺組織内の酸 P-ase および protease 含有量

\begin{tabular}{|c|c|c|c|c|}
\hline 症例 & 年令 & $\begin{array}{l}\text { 酸 P.ase } \\
(1 \mathrm{~g} \text { 当り) }\end{array}$ & \begin{tabular}{|} 
Protease \\
$(1$ g 当り $)$
\end{tabular} & 診 断 \\
\hline 1 & 46 & 0.18 & 22.6 & 前立腺結石 \\
\hline 2 & 64 & 0.17 & 1.2 & 膀胱腫㾴 \\
\hline 3 & 55 & 0.16 & 10.4 & "I \\
\hline 4 & 63 & 0.34 & 8.8 & $\begin{array}{c}\text { 膀胱腫瘍十 } \\
\text { (前立腺腺腫) }\end{array}$ \\
\hline
\end{tabular}

第 2 表 前正腺腺腫組織内の酸 P-ase 括よび protease 含有量

\begin{tabular}{|c|c|c|c|c|}
\hline 症例 & 年令 & 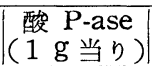 & $\begin{array}{l}\text { Protease } \\
(1 \mathrm{~g} \text { 当り) }\end{array}$ & 病理組織像 \\
\hline 1 & 70 & 3.01 & - & $\mathrm{I}$ \\
\hline 2 & 53 & 1.56 & 11.6 & I \\
\hline 3 & 68 & 1.49 & 6.2 & $\bar{I}$ \\
\hline 4 & 58 & 1. 13 & - & I \\
\hline 5 & 70 & 0.95 & 4.0 & I \\
\hline 6 & 65 & 0.61 & 13.9 & I \\
\hline 7 & 78 & 0.19 & 8.8 & I \\
\hline 8 & 76 & 0.70 & 13.2 & I \\
\hline 9 & 64 & 0.86 & 8.0 & $\mathrm{I}$ \\
\hline 10 & 61 & 0.36 & - & II \\
\hline 11 & 74 & 0.34 & 12.0 & II \\
\hline 12 & 72 & 0.29 & 4.5 & II \\
\hline 13 & 71 & 0.72 & 13.0 & II \\
\hline 14 & 72 & 0.08 & 8.0 & III \\
\hline 15 & 59 & 0.21 & 11.3 & III \\
\hline 16 & 68 & 0.21 & 4.0 & III \\
\hline $17 *$ & 74 & 0.21 & 6.4 & I（癌を合併） \\
\hline
\end{tabular}

*この症例は前立腺肥大症として腺腫剔除を行ない, 組 織学的にその一部に癌病巣が証明されたもので,この 症例では腺腫部分と癌部分について別々に酵素を測定 した。 
0.18 と略々一定して拉り，0.34とや〉高い值を示した 1 例は病理学的には前立腺肥大症といえるものである（第 1 表).

(b) 前立脉肥大症 (腺腫) 組織内の酸 P-ase

(i) 発情物質非投与の前立腺腺腫組織内の酸 P-ase (17例, 第 2 表)

術前に estrogens投与を行なわずに剔除した腺腫組織 についての酸 P-ase含有量を測定したものである.

前立腺肥大症の場合の組織内 P-aseの含有量に柱かな りのちがいがある.だ゙病理組織学的に比較的腺管構造 がよく発育した腺腫では $1 \mathrm{~g}$ 当りの酸 P-ase 含有量は 0.70 3.01(第 7 例灾けは0.19 と低值であるのを除けば) を示し，大ょそ 1.0 単位前後ということができる．とれ は腺腫以外の前立腺組織内含有量にくらべると, 完成さ れた前立性腺腺腫では明かに酸 P-aseの含有量はかなり 多いということができる(第1表をも参照).

これに対し，前立腺肥大症でも腺管構造の間質組織に 対し占める割合が比較的少い著者のいう II 型挔よび开型 では，酸 P-ase含有量はやはり前者に比して少く0.08〜 0.36 単位の間にあり, 大ょそ $0.2 \sim 0.3$ 単位前後である
(第13例だけは0.72単位とや>高い).しふし, 腺腫以外 の前立腺組織と比較すると，酸 P-aseの含有量はすずか ではあるが多いということができる. 第 1 表中の第 4 例 なぞもとの好例といえる.

これは組織内の酸 P-ase含有量の多寡はある程度まで 腺管構造の発達の状態と平行していること, それと同時 にこのことはまた，前立腺腫痬というものが機能的にも 正常前立腺と同じょうに，あるいはれそれよりも活発な 分泌機能を保持していることをも示している．したがつ て, 正常の場合のようにこの酸 P-ase分泌機能が主とし て男性ホルモンの支配下にあるとすれば，前立腺腺腫の 酸 P-ase分泌機能む同じように男性ホルモンの支配を受 けていると見るとこができる。

(ii ) 発情物質投与後の前立腺腺腫内の酸 P-ase（21 例, 第 3 表).

いずれも手術前に合成発情物質である hexestrol を投 与してから腺腫剔除術を施行し, その腺腫組織について (i) と同じょう酸 P-aseを測定した. Hexestrol の 投与量はや>区々であるが, はじめのころは 1 日10mg 〜30mg，総計 $100 \mathrm{mg}$ 前後を同様に投与したもので，それ

第 3 表 発情物質 (hexestrol) 投与後の前立腺腺腫組織内の酸 P.ase おちよび protease 含有量

\begin{tabular}{|c|c|c|c|c|c|}
\hline 症 例 & 年 令 & $\begin{array}{c}\text { Hexestral } \\
\text { (投与量 } \times \text { 日数) }\end{array}$ & $\begin{array}{l}\text { 酸 P-ase } \\
(1 \mathrm{~g} \text { 当 } \eta)\end{array}$ & $\begin{array}{l}\text { Protease } \\
(1 \mathrm{~g} \text { 当 })\end{array}$ & 病理組織像 \\
\hline 1 & 74 & $60 \mathrm{mg}(15 \times 4)$ & 1.15 & - & I \\
\hline 2 & 75 . & $71 \mathrm{mg}(27 \times 3)$ & 0.56 & - & I \\
\hline 3 & 65 & $90 \mathrm{mg}(15 \times 6)$ & 0.55 & - & II \\
\hline 4 & 64 & $90 \mathrm{mg}(15 \times 6)$ & 0.53 & - & II \\
\hline 5 & 65 & $90 \mathrm{mg}(15 \times 6)$ & 0.48 & - & I \\
\hline 6 & 72 & $100 \mathrm{mg}(10 \times 10)$ & 0.57 & 0.5 & I \\
\hline 7 & 66 & $120 \mathrm{mg}(\overline{6 \times 20})$ & 0.42 & 0.5 & II \\
\hline 8 & 71 & $120 \mathrm{mg}(30 \times 4)$ & 1.76 & 9.5 & I \\
\hline 9 & 83 & $180 \mathrm{mg}(6 \times 30)$ & 0.48 & 2.4 & I \\
\hline 10 & 69 & $210 \mathrm{mg}(30 \times 7)$ & 0.83 & 8.0 & I \\
\hline 11 & 65 & $210 \mathrm{mg}(30 \times 7)$ & 0.45 & - & I \\
\hline 12 & 75 & $210 \mathrm{mg}(30 \times 7)$ & 0.20 & 5.0 & I \\
\hline 13 & 73 & $240 \mathrm{mg}(30 \times 8)$ & 0.76 & - & II \\
\hline 14 & 76 & $240 \mathrm{mg}(30 \times 8)$ & 0.05 & 7.0 & III \\
\hline 15 & 78 & $240 \mathrm{mg}(30 \times 8)$ & 0.00 & - & II \\
\hline 16 & 73 & $270 \mathrm{mg}(30 \times 9)$ & 0.93 & - & I \\
\hline 17 & 73 & $270 \mathrm{mg}(30 \times 9)$ & 0.12 & 0.0 & II \\
\hline 18 & 62 & $300 \mathrm{mg}(30 \times 10)$ & 0.17 & 4.0 & II \\
\hline 19 & 72 & $330 \mathrm{mg}(30 \times 11)$ & 0.98 & 1.0 & I \\
\hline 20 & 73 & $480 \mathrm{mg}(30 \times 16)$ & 0.16 & 13.1 & II \\
\hline 21 & 70 & $510 \mathrm{mg}(30 \times 17)$ & 0.10 & 11.4 & II \\
\hline 22 & 75 & 除鋅術（14日後） & 0.00 & 0.0 & II \\
\hline
\end{tabular}


以後の大部分で総計 $200 \mathrm{mg}$ 以上 (平均して 1 日 $30 \mathrm{mg} 7$ 〜10日以上）を投与してから腺腫剔除術を行つた。酸 P-ase の腺腫内含有量注第 3 表のような成績であつた。

まず $100 \mathrm{mg}$ 以下の hexestrol 投与後の腺腫組織内の酸 P-ase 忙最大 1.15 単位, 最少 0.48 単位であるが，大部分は

0.5単位を示している.これは hexestrol 非投与群の腺 畽組織内の含有量とくらべて多少は減少しているこいえ るが，そのちがい極めてわずかである.したがつて腺 腫内酸 P-aseの分泌機能は，発情物質の $100 \mathrm{mg}$ 程度の投 与によつては，多少は抑制されるとしてもまずあまり強 くその影響を受けるでとはないといつてもよいようであ る. 同様のこさは，発情物質 $100 \mathrm{mg}$ 以上小ら $200 \mathrm{mg}$ 程度 までの投与についてもいえる．発情物質 $200 \mathrm{mg}$ 以上に投 与についても0.76, 0.93，0.98（第13表の13例，第16例 第19例なぞ）のように hexestrol 非投与群と同じょう な酸 P-ase 活性を示すものも存在するが，0.2単位前 後からそれ以下のものも約半数において認められる.つ ま前立腺腺腫では，100〜 300mgす発情物質投与によ つてその酸 P-ase 産生機能は多少抑制される傾向がな いとはいえないが、一般的にいえばそれ程強い抑制影響 を受けていないといることができる。またとの範囲の発 情物質投与量によつては, 病埋組織学的にその影響と思 われる腺細胞のごく軽微な篓縮退行変化を認めるものも 一部に存在したが，それも極く部分的局所的なむので， その大部分に执いてははつきりと発情物質投与によると 指摘できる病理組織学的変化を確認することはできなか つた.

すなわち，前立腺腺腫は正常前立腺組織よりもかなり 高い酸P-ase産生機能をもつで抢り，ての機能注当然体内 の男性ホルモン分泌状況の支配下にあると考えられる が，この男性ホルモンの作用に拮抗するはずの発情物質 の投与によつて，形態的のみならず，醰素活性から見た 機能にも殆んで影響をうけていないと考えるととができ る.な挔，第 3 表第 22 例湔前腺肥大症とかなり進行し 前立腺癌を併発していたもので，乙れは除䔂術を行なつ た14日後に腺腫だけを剔除したわけであるが，ての腺腫 内には酸 P-eseを測定するととができなかつた。しかし 腺腫部分には組織学的にまだはつさりと除鋅術の影響と 思すれる形態学変化は確認していない。それにもかかわ らず，機能的の面では酸 P-ase (protease も同様) の 産生が全く抑制されている，わずか 1 例の成績ではある が，発情物質投与群の成績と対照して興味ある所兒であ つた。これについては後章でも触れることにする。
（C）前立腺癌組織内の酸 P-ase

（i）ホルモン療法を行なわなかつた前立腺組織内の 酸 P-ase ( 9 例，第 4 表).

第 4 表 前立腺癌組織内の酸 P-ase および protease 含有量

\begin{tabular}{|c|c|c|c|c|}
\hline 症例 & 年令 & 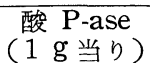 & $\begin{array}{c}\text { Protease } \\
(1 \mathrm{~g} \text { 当り) }\end{array}$ & \begin{tabular}{|l}
$\mid$ 病理組 \\
織像
\end{tabular} \\
\hline 1 & 68 & 0.98 & 5.2 & I \\
\hline 2 & 71 & 0.70 & 6.7 & I \\
\hline 3 & 60 & 0.21 & 10.0 & I \\
\hline 4 & 80 & 0.20 & - & I \\
\hline 5 & 55 & 0.42 & 11.4 & I \\
\hline 6 & 65 & 0.87 & 9.6 & II \\
\hline 7 & 68 & 0.51 & 12.5 & II \\
\hline 8 & 67 & 0.55 & 23.4 & I \\
\hline $9 *$ & 74 & 0.21 & 8.2 & I \\
\hline $10 * *$ & 68 & 1.01 & 8.8 & II \\
\hline
\end{tabular}

* この症例は第 2 表の第17例で（肥大症と癌の合 併), ここでは癌病巣について測定した酵素含有量 である。

**これは本表の第１例で根治的前立腺剔除術を行な つた際に剔除した 1 個の骨盤リンパ腺転移癌組織 の測定值である。

前立腺癌組織内の酸 P-ase ( $1 \mathrm{~g}$ 当り) は $0.2 \sim 0.22$ 単位已正常前立腺組織内のそれと同じ程度の含有量を示 すむのもあるが，過半数に执いては 0.5 単位から 1.0 単 位弱とそれよりかなり高い含有量を示している。つま り，酸 P-asek関するかぎり，前立腺癌組織内含有量 は前立腺腫のそれそほこんぞ同じであるということでが きる，つまり，悪性腫瘍である前立腺癌細胞も正常前立 腺と同じくあるいはそれょりも活発な酸 P-ase産生機能 をむつて抢り，したがつて同じょうに男性ホルモンの支 配下にある。乙の前立腺癌に打ける酸 P-ase含有量と病 理組織像との間にははつきりとした関係は認めることは できなかつた。いいかえると腺管構造の未分化のもので も，その癌細胞恃男性ホルモンの支配下にあつてむしろ 正常よりもかなり高い酸 P-ase産生能を保持していると 考えられるものである．（第 3 章をも参照）.

(ii) 発情物質投与後の前立腺癌組織内の酸P-ase ( 9 例，第 5 表).

第 5 表の第 1 例はその組織内酸 P-aseも0.53 と非投与 の前立腺癌とほとんど差がなく, これは恐らく hexestrol の投与量がわずかに $45 \mathrm{mg}$ 己少量のためその響影をうけな かつたものであろう。とれに対し，少くとも hexestrol $100 \mathrm{mg}$ 以上を投与された場合に浪癌組織内の酸 P-aseは 
第 5 表 発情物質 (hexestrol) 投与後の前立腺癌組織内の酸 P-ase 拈よび protease 含有量

\begin{tabular}{|c|c|c|c|c|c|}
\hline 症 例 & 年 令 & $\begin{array}{c}\text { Hexestrol } \\
\text { (投与量 } \times \text { 日数) }\end{array}$ & $\begin{array}{l}\text { 酸 P-ase } \\
(1 \mathrm{~g} \text { 当 り) }\end{array}$ & $\begin{array}{c}\text { Protease } \\
(1 \mathrm{~g} \text { 当り) }\end{array}$ & 病理組織像 \\
\hline 1 & 63 & $45 \mathrm{mg}(15 \times 3)$ & 0.53 & - & I \\
\hline 2 & 80 & $105 \mathrm{mg}(15 \times 7)$ & 0.00 & - & I \\
\hline 3 & 78 & $144 \mathrm{mg}(24 \times 6)$ & 0.05 & 1.6 & I \\
\hline 4 & 62 & $210 \mathrm{mg}(30 \times 7)$ & 0.09 & 6.4 & $\mathrm{I} *$ \\
\hline 5 & 73 & $270 \mathrm{mg}(30 \times 9)$ & 0.05 & 0.0 & $\mathrm{I} *$ \\
\hline 6 & 68 & $300 \mathrm{mg}(30 \times 10)$ & 0.00 & 0.0 & I \\
\hline 7 & 79 & $300 \mathrm{mg}(30 \times 10)$ & 0.06 & 1.6 & I \\
\hline 8 & 64 & $420 \mathrm{mg}(30 \times 14)$ & 0.06 & 0.0 & II \\
\hline 9 & 67 & $660 \mathrm{mg}(30 \times 22)$ & 0.03 & 6.6 & $\mathrm{I} *$ \\
\hline $10^{* *}$ & 67 & $660 \mathrm{mg}(30 \times 22)$ & 0.05 & 6.2 & $I *$ \\
\hline
\end{tabular}

* 癌細胞のごく一部に核の濃縮あるいは崩壊像, 原形質の空胞化を生じているが, 癌巣全体としては それほど著明の変化とはいえない。

**これは本表の第 9 例で, 骨盤腔にあつた巨大なリンパ腺転移癌組織の一部を切除した標本について 測定したものである。

全部が 0.1 単位以下，なか汇は全くその活性が㧕制され て測定できなかつたもの（第 2 例，第 6 例など）さえあ る.もちろん，300mg以上の投与になると多少とも癌細 胞の萎縮退行すなわち核の濃縮あるいは崩癌像, 原形質 の空胞化なぞ明らかに hexestrol の影響による形態学的 变化を認めるが，いずれもこれは極めて軽度のもので， またごく一部分に限局していた。

とのように，発情物質 (hexestrol) 投与による前立腺 組織内の酸 P-ase 産生機能の抑制柱, 前立腺之前立腺 癌とでは明らかなちがいを示して抢り，癌に抢いてはと の酸 P-ase 産生機能は, 前立腺腺癌ではほとんぞ影響 がなかつた㴽ぶ同量の発情物質によつてすでに強く抑制 きれている。しかも，乙の機能抑制は，発情物質认よる 㿔細胞の形態学的变化方全くあるい怪軽度にしか見られ ないろちに，てれに先立つて発現している。つまり，酸 P-ase 活性から見た前立腺癌細胞の機能以, 自律性の悪 性腫浜でありながら，良性腫瘍である前立腺腺腫よりは 男性ホルモンの支配が強いといら現象が認めら㣗ること 《なる。

(iii) 除鋅術後の 前立腺組織内の酸 P-aes（2 例,

\section{6 表)}

この測定例注 2 症例だけで，いずれも0.08単位および 0.10 単位を示している，症例は少いが，除粹術後 2 週間 前後までの前立腺癌組織に対する影響は惊ざ hexestrol 投与群のそれと同じかそれよりはや>弱い㑯向を示して いる.ただし除睪術の前立腺癌細胞に対する組織学的影 響は hexestrol 投与よりもかなり高度に発生してい っ.つまり，形態学的な影響住除莘術の万がより早くよ 的著明に発現，心い小える亡，この点では抗男性ホルモ
第 6 表 除嶭訹後の前立腺癌組織内の酸 P-ase 扰よ び protease 含有量

\begin{tabular}{|c|c|c|c|c|c|}
\hline 症例 & 年令 & 除辜術後 & $\begin{array}{l}\text { 酸 P-ase } \\
(1 \mathrm{~g} \text { 当り) }\end{array}$ & $\begin{array}{l}\text { Protease } \\
(1 \mathrm{~g} \text { 当 })\end{array}$ & $\left|\begin{array}{|l}\text { 病理組 } \\
\text { 織像 }\end{array}\right|$ \\
\hline 1 & 70 & 14 日 & 0.08 & 0.0 & {$\left[\begin{array}{l}\text { 未分化 } \\
\text { 腺癌 } *\end{array}\right.$} \\
\hline 2 & 57 & $\begin{array}{c}14 \text { 日 } \\
\text { Hexestrol } \\
500 \mathrm{mg} \\
(50 \times 10)\end{array}$ & 0.10 & 14.4 & $\begin{array}{r}\text { 䯣様癌 } \\
*\end{array}$ \\
\hline
\end{tabular}

*除闰術の影響と思われる細胞質の空腔化と壊死が部 分的に認められた。

ン療法としては除孟術の方がより drastic ともいえるか もしれないが，酸 P-ase産生という機能的な影響は発情 物質投与の方がむしら早く発現する傾向もあるように考 えられる.

（B）アルカリP-ase の測定成績

酸 P-aseの測定と同封に同じ，サンプルの一部につい てアルカリ P-aseの含有量も測定した。しかし，著者の 実施した測定法（2 章を参照）によつてば，正常前立腺 の及ならず前立腺肥大症拉よび前立腺癌のいずれの組織 に执いでもアルカリP-aseは測れなかつた。つまり，と 礼.ら前立腺組織にはとの抽出液の 50,000 倍稀釈液では測 定できない程度の少量のアルカリ P-aseしか含有されて いないといつてよい（後章をも参照）。

(C) Protease の測定成績

こ衣も酸执よびアルカリP-ase測定に用いたのと同じ 組織抽出液の一部について測定したものである.

（a） 正常前立腺組織内の protease (第 1 表). 
第 1 表に示すように, protease の含有量は最少 1.2 単位, 最高は22.6単位で, 酸 P-aseの場合のように㴽ぶ 一定した值は得られなかつた。 たざ第 1 表, 第 1 例は慢 性前立腺炎学む合併して抢り protease の高值はこれに 関係があるかもしれない。

（b） 前立腺肥大症（腺腫）組織内の protease

（i）発情物質投与を行なわなかつた前立腺腺腫組織 内の protease (第 2 表)

腺腫内のprotease 含有量は最少 4.0 単位, 最高々 13.9 単位で大部分は 10.0 単位前後の含有量ということができ る. また, 酸 P-ase と添ぶ同様に, この protease 含 有量の多宣と病理組織との間にははつきりした関係は認 められなかつた。

(ii ) 発情物鋇投与後の前立腺腺腫組織内の protease (第 3 表)

発情物質 (hexestrol) を投与したのちに剔除した前 立腺腺腫内の protease 含有量は最高13.1単位から11.4 単位おふび 9.5単位なぞこ比輍的高い值を示すものもあ るぶ（第 3 表の第 20 例, 第21例, 第 8 例など）, 半数に おいては 2 単位か10単位以下であつた。つまりある程度 はその protease 厓生機能が発情物質によつて抑制され ていることを認め得る. しかし, てれは必ずしも発情物 質の投与量に比例するものではなく，むしろ $500 \mathrm{mg}$ と大 量になるとかえつて protease 活性法高められると考え られるような成績であある。これについては後章で触れ ることにする。

(C) 前立腺癌組織内の protease

（i）ホルモン療法を行なわなかつた前立腺癌組織内 ๑ pratease 、第 4 表)

無治療の前立腺癌組織内の protease 含有量注 5.2 単 位あるいは 6.7 単位程度のものむあるが（第 1 例，第 2 例）大部分は10単位を越えており，ての protease 含有 量は発情物質非投与の前立腺腺腫群のそれとほぶ同じと いうことができる。つまり，前立腺腺腫と前立腺癌に预 ける protease 産生機能ではとくに差異はないと見てょ い. また, この protease 含有量と病理組織像との間に むはつきりした関係は認められなかつた．この点は酸 p-ase の場合を同様であつた。

(ii) 発情物質投与後の 前立腺癌組織内の protease (第 5 表)

発情物質 (hexestrol) 投与後に採取した前立腺穕組 織内の protease 含有量は 6.0 単位を示すものもむるが （第 4 例，第 9 例），大部分では 1.0 単位前後か，ある
いは全く測定されないものであつた（第 5 表, 第 5 例, 第 6 例执よび第 8 例).つまり, protease についてみる そ, 前立腺癌組織では発情物質によつてその機能がかな り強く抑制されることを示している. 第 3 表のように前 立腺腺腫で protease 産生機能が必ずしもはつきりとは 抑制されないのと異り, 前立腺痁では酸 P-aseのそれと 同じように発情物質によつてはつきり己抑制的影響を蒙 つていると考らることができる.

(iii) 除睪術後の前立腺癌組織内の protease （第 6 表)

第 6 表の第 1 例では除䔂術14日後の前立腺癌組織内に はすでに protease を証明しないのに対し，第2 例（能道 様癌)では proteaes だけは無影響で14.4単位を示して いる. 両症例とも組織学的には除莘術认よる形態的変化 がある程度はつをり発現しているのに，第 2 例だけなぜ protease 值が低下していないのか例数が少いのでその 機序は不明だが，あるいは発情物質の投与などもこれに 関係あるのかも知れない.

\section{IV 総括と考案}

前立腺の形態掞よび機能が男性ホルモンに強く支配さ れているととは周知のとおりであるが，自律性発育を 特徵とする前立腺癌という悪性腫济も正常前立腺と同じ ようにその発有增殖は男性ホルモンに依存している。こ れが前立腺癌のホルモン依存性, 具体的にいえば男性ホ ルモン依存性癌 (androgen-dependent cancer) の第一 の条件である. この生物学的性状を利用して発展したも のが前立腺癌のホルモン療法, いわゆる抗男性ホルモン 療法である. この治療法によつて癌組織の萎縮退行を生 ずることが男性ホルモン依存性瘤の第 2 の条件である. そしてての治療法が Huggins ら (1941) によつて提唱 実施されて以来, 前立腺癌は悪性腫瘍でありながらホル モンによつてコントロールされ得るということは, 確寒 な臨床的実事となつているわけである. そしてての蕙づ けとなる病理組織学的検索はすでにいくつか発表されて 㧍り，また間接的ではあるが血清の酸 $\mathrm{P}$-ase の消長なぞ による生化学的検索の裏づけこなる論文もいくつか報告 されている (馬場, 1959 ; 糸井, 1959 ; 松村, 1959 ; そ の他).しかし, 前立腺癌組織そのものについて，てのホ ルモン依存性ということ学生化学的な面から詳しく検索 しな研究はほとんどないといってよい，その最大の理由 の一つは生化学的ある沿い薬理学的にそのホルモン依存 性を研究するための十分な量の材料を採取することが， 前立腺癌では甚だ困難だからである。このために，これ 
までホルモン依存性という前立腺癌組織そのものの機能 的な面の研究データがまだそしいわけで，乙の方面の検 索沈ルモン療法という広い意味での癌の化学㙩法の新 たな発展への手掛りを与えるものでもあるといえる。

ところが同じ前立腺から発生しながら, 前立腺肥大症 乙前立腺癌とはいろいろな点で極めて対照的なちがいを 示している.もちろん, 前立腺癌と前立腺肥大症とでは 病理学的にむいろいろとちがつている. たとえぱ, 前立 腺肥大症は前立腺という同じ母地のうち前立腺のいわゆ る内腺 (inner glands) から発生するのに対し, 前立腺 癌の方は本来の前立腺組織である外腺 (outer glands) に発生する. また, 病理学的には多少の異論はあるが前 立腺肥大症は腺腫というあくまで良性の腫瘍性新生物と 考えてられおり，乙れに対し前立腺癌ははじめから悪性 腫晹としての特徵的な性状（浸潤性発育, 転移など）を もつている. それにもかかわらず機能の点では著しくち がつている，たとえば, 悪性腫瘍である前立腺癌の発育 㳉ホルモンによつてコントロールされ得るのに, 前立腺 肥大症ではこ机までの臨床的経験からも深とんどホルモ ン依存性を示していない。しかし，上述した材料採取の 困難なとこなども大きな理由となり，乙のホルモン依存 性のちがいを生化学的に比較した研究沙当らない。

著者がこの研究を企図したのは大よそ上に述べた $2 つ$ の事項を重点的にとり上汭，乙れを生化学的な面からな るべく定量的に検索追求したいと考えたからである. そ してての検索法として選んだのが, 前立腺組織に特有と される酸 P-ase および protease で, これらの醳素の 前立腺腫場組織内に拈ける含有量とホルモンによるその 消長を測定したものである. その測定成績は第 3 章に記 載したと抢りであるが，一応その成績を総括するととも に，てれを基に若干の考察を行なつて見る.

(A) 酸 P-aseについて

前立腺組織には後述する蛋白分解醭素 (protease) や $\beta$-glucronidase などの外, 酸 P-ase が含まれている.

(Mann. 1954 ; その他). しかも前立腺内の酸 P-ase怡血 清中のそれの $10^{5} \sim 10^{6}$ (Gutman 万, 1938), 組織 $1 \mathrm{~g}$ 当り $5,000 \sim 40,000$ Bodansky 単位 (Tagnon, 1960) あ るい注 8,000〜14,000 Gutman 単位 (Kirk ら, 1962) と極めて多量でる。.また Goetsch (1960) む組織化 的学にてれを証明している，たとえば，正常前立腺では

アルカリ P-ase は小葉の上皮には含をれず管上皮内に わずかに存在するだけであるが, 酸 P-aseの方虫小葉の 久ならす゚管上皮内にも多量に含まれて㧍り，しかもそれ
は主として細胞の管腔に面した外方 ${ }^{1} / 3$ の部分に限局して いるという。これほど妳はずれに大量の酸 P-aseを含有 する蔵器注前立腺だけであり，ての意味で酸 P-ase注前 立腺に特有な酻素といつてもよいものである。しかもこ の酸 P-ase 生生能は 前立腺機能と平行している. この 前立腺機能は男性ホルモンの直接の支配下にあるから, 酸 P-ase の産生能も当然男性ホルモンの 分泌状況乙平 行して扣り，したがつて前立腺の酸 P-ase 産生状態は 間接的であるが男性ホルモンの分泌状況の指標とする ことができる (Huggins ら，1940，1942）などまた前 立腺腫場々くに前立腺癌ではその発生母地たる正常前立 腺と同じくこの酸 $\mathrm{P}$-ase 産生能を保持して抢り, 前立 腺癌に掞いてその転移の有然あるいはホルモン療法に上 る癌発育增殖の消長を知る好指針として，血清中の酸 P-ase 測定が不可久な検查法となつているわけである. 著者が前立腺腫場のホルモン依存性を生化学的に検索す るすにその指標の一つとして酸 P-aseを選んだのもこの ためである。

正常前立腺, 前立腺肥大症捛よび前立腺癌組織内の酸 P-ase 含有量さホルモン療法によるその消長を測定検索 した著者の成績は以下のように総括できる（第 3 章をも 参照).

正常前立腺組織 $1 \mathrm{~g}$ 当りの酸 P-ase含有量以著者の測 定法によれぱ，全く正常の組織では0.16〜0.18単位と法 ぶ一定した值を示していた. 1 例は 0.34 とや〉高いがこ れは組織学的にも初期腺腫の像をむつていたものであ る(第 1 表, 第 4 例)．測定法がちがうのでそのまま比 較はできないが, この測定值はこれまでの報告のものと 大差はない (Tagnon, 1960 ; Kirk ら 1962なご).

前立腺肥大症 (腺腫) 組織についての酸 P-ase含有量 以最高3.01単位から0.08単位とかなりの差異を示してい る (第 2 表). これは大よそ腺腫の組織像と関連してい る. ずなち, 著者の規定した分類の第 1 型, 腺管構造 のよく発達した腺腫では 1.0 単位以上あるいは 1.0 単位 前後の值を示して括り，第 2 型ではや〉少なくて 0.4〜 0.3 単位, 第 3 型では 0.2 単位前後の值であつた. との ことは前立腺腫であ正常前立腺と同様に酸 P-ase は 腺小葉抢よび腺管上皮内に多量に含まれているという Goetsch (1960) の組織化学的検索成績とも一致する. とのように前立腺腫の酸 P-ase 含有量以病理組織像に よつてかなりの変動を示してはいるが，少くとも著者の 定量測定成績からすれば, 前立腺腺腫組織は明名に正常 前立腺組織よりも多量の酸 P-ase を含有しているとい うことができる，ま䒘同時に，酸 P-ase を指標とした 
ところでは，前立腺腺腫も男性ホルモンの支配下にある ということがべきる。しかし，乙の腺腫が男性ホルモン 依存腫湯の範疇にはいるものと断定するわけにはいかな い. この点学次の実験成績によつて考察して見る.

予め発情物質 (hexestrol) を投与してから剔除した 前立腺腺腫組織の酸 P-ase含有量は第 3 表に示すような 成績であつた。これは投与した hexestrol の量が必ずし も一定していないので個々を比較するわけにはいかない が,汪ざ以下のように要約するととができよう, 酸 P-ase 産生能の 抑制は投与量によつてちがうわけであるが,

$100 \mathrm{mg}$ 程度の投与量では極めて軽度，200〜 300mg とな ると一応酸 P-ase産生能の抑制がある程度はつきりと 確認される。しかしそれでは大よそ $1 / 3$ 程度抑制されるに 過ぎないょうで，とくにてれは腺管のよく発育した第 1 型に認められる。もちろん hexestrol のこの投与量では 腺腫の形態学的変化性全くあるいは浮とんご発生してい ない。すすおち，前立腺肥大症（腺腫）も発情物質投与 によつて酸 P-aseの攵生能が抑制されることは確かであ るが，200〜 300mgでは極めて軽度にすぎないといつて よい. いいかえると, 前立腺腺腫の酸 P-ase産生能汶正 常よりも明かに旺盛で，乙のかぎりでは男性ホルモン依 存性の腫瘍といえないととはないが，抗男性ホルモン法 療による酵素攵生能の抑制作用はあるとしても極めて軽 微であり，後述する前立腺癌のような意味の男性ホルモ ン依存性癌という性状は確認できなかつた。 たぶ除粹術 を行つた 1 例(第 3 表, 第22例)は術後14日で剔除した腺 腫に扢いて, 組織像に漂とんぞ变化がないのに酸 P-ase 值 (protease む) は 0 であつた。前立腺肥大症には除睪 術が涪とんぞ効ないととは臨床的にも経験されている。 ところがこの症例は除宰術によつて腺腫内の酸 P-ase攵 生能が完全に抑制されるととを示している. しかし， 1 例だけなので常にてのような成績になるかどうかは未定 であるが，興味ある所見とも考えられる。

前立腺癌組織内の酸 P-ase含有量は最高0.98単位, 最 少忟 0.20 単位であるが過半数忧 $1.0 \sim 0.4$ 単位の間にあ る(第 4 表を参照). そしてての值は, 前立腺癌の病理組 織像, 分化した腺癌加未分化癌かによつてもとくにちが つてはいない,ずなうち, 前立腺癌の酸 P-ase 含有量 は組織学的な分化, 未分化というととょりは, むしろ癌 組織中の癌細胞の多宾に関係しているということがで きる. てれは前立腺癌の酸 P-ase についての Goetsch (1940) の組織化学的検查成績とも一致している. 彼に よると, 前立腺癌に抢ける細胞内の酸 P-a se 分布は全
く不規則で，たざどちらかと云えば小葉構造を示す部分 に执いて管腔に面した側にや>多量に存在する。しかし 未分化癌ではとくにその分布は一定して捛らず，間質内 に浸潤增殖している癌細胞では細胞質全体に存在する。 な抬前立腺小葉捛よび管腔内に存在する分泌液中には 正常のみならず腺腫打よび癌腫に抢いてもいずれも 酸 P-ase は濃縮されて証明されるという。一方末 た, Woodard (1952), Downey ら (1954) あるいは Marberger ら (1956) によると. 前立腺腺腫と癌とで は酸 P-ase の組織内含有量は後者の方がかなり低いと いう．著者の成績でも，癌腫の方が腺腫より酸 P-ase 含有量はや〉少いという一般的傾向を示してはいるが過 半数は 0.4〜 1.0単位の間であり (少数が 0.2 単位), 癌 腫と腺腫この間で組織内 P-ase含有量に有意な差を認め るととはできなかつた、いずれにしろ, 前立腺癌組織の 酸 P-ase 含有量は正常前立腺組織よりも明示に多いと いえるもので，乙の意味では前立腺腺腫と同じょうにそ の酸 P-ase 原生能 は正常よりは確かに旺盛だというこ とができる。

次に発情物質 (hexestrol) を投与した後に採取した 前立腺癌組織の酸P-aseを測定すると,とれではその攵生 能が著明に抑制されていることが認められた（第 5 表を 参照).Hexestrol 45mg投与（第 5 表，第 1 例）ではその 抑制作用はな扮現われていないが，100mg以上の投与例 ではその酸 P-ase産生能は対照群とくらべて有意の差を もつてはつきりと抑制されている，ただし、著者の行つ た hexestrol 投与量では病理組織学的な变化牥拣とんと ないか, あつても軽微なものであつた。 それにもかかわ らず, 酸 P-ase㕍生能といら機能の面では極めて鋭敏に 発情物質の抑制的影響をうけている。乙れは前立腺癌が 男性ホルモン依存性癌であることを醭素学的にはつきり 襄づけし得た成績である．とのととは同時に前立腺腺腫 の酸 P-aseの消長とも著明な対照を示しているもので, 前立腺腺腫はホルモン依存性腫瘍とはいえないわけであ る.なお 2 例では除尝後術の前立腺組織内の酸 P-aseを 測定したが (第6 表)，第 1 例では酸 P-aseは著明に拂 制されたのに対し，第 2 例はそれ湶どでなかつた。 との 理由は不明だが，あるいは Brendler (1960) のいう除 鋅術の遅発効果のためかもしれない。

(B) アルカリP-ase について

第 3 章で述べたょうに, アルカリP-ase は正常前立腺 のみならず，前立腺肥大症扮よび前立腺掂組織では測定 できるだけの量々存在しなかつた。すなわち、組織抽出 
液 50,000倍稀釈では前立腺内にはアルカリP-aseは測定 し得ない程度, しいていえば精々10ー100稀釈液で測 定できる程度の量しか含まれていない.すでに Goetsch (1960) 注組織化学的にアルカリP-ase は腺小葉の上 皮には含まれず腺管上皮内に僅かに証明されるにすざな いといつて招り，著者の測定成績も定量的にこれを確め 得たわけである。

(C) Protease について

著者が前立腺腫痬のホルモン㳖存性の指標としてprotease という酥素を選んだの法次の理由からである。

ヒトの精液中に一種の蛋白溶解醭素の存在するととを 推定したのは Huggins ら (1942) であるがその後に至 りこれが確認されている (Mann, 1954; その他).ま た広沉な転移を生じた前立腺癌では強い出血傾向 とか 溶血現象を続発するととが臨床的㳗験されている. Tagnon弓 (1952) ほこのような血液性状の变化が plasmin systemの賦活によるものではなく, むしろ前立腺 中に含有される蛋白溶解醭素が血中に流出したために発 生したためではないかと推定した。 さらに Tagnon ら (1953)注前立腺組織の食塩水抽出液がfibrinogen 抢よで fibrin を溶解することを in vitro で認めた発表をした。 Lombardo ら 1958,1959$)$ も加熱 fibrin平板法により組 織抽出液が fibrin を溶解ずることを確めている. このよ うにして, 正常前立腺のみならず前立腺腫場組織には蛋 白溶解能をもつ一種の醉素がかなり多量に含まれている ことは確かと考えられるに至つている, しかし, てれが果 して TagnonらやLombardoらがいうようにfibrinolysin そのものかどうかについてはな打異論がないわけではな い. たとえば Prout ら (1956) は転移をもつ前立腺癌 患者血清にはウマの fibrinogen-thrombin clotを溶解卞 る作用はなく，乙㣗に streptokinase-streptodornaseを 添加してはじめて fibrinolytic な活性を示すものだとい 3. Laderhoff 万 (1961) 牥前立腺腺腫は KSCN 抽出液 でplasminogen activatorを測定し,とのものが多量に含 まれているという成績を発表している。黒田ら (1962) 㳂前立腺腺腫の生理食塩水抽出液には plasmin actiator とその proactivator 汢存在するが plasmin汸含まれて 扔らないと報告している。

著者らの測定は Casein-Folin 法によつたもので, 上 述したような点から，とれによつて測定されたものを一 応 proteaseとしたものである。

正常前立腺組織の protease 含有量は個人差が大きく 一定していないようである (第 1 表).
前立腺腺腫織組内の protease むある程度の個人差を

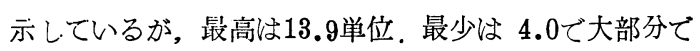
汶 8.0 10.0単位前後と夕てよい(第 2 表).との含有量 と組織像との間には特別の関連は認方られなかつた。 予 め発情物質を投与した後汇剔除した前立腺腺腫内の protease は $200 \mathrm{mg}$ 以上の投与量で逆沈しろ高值を示すむ のが 2 例 (第 20 , 第21例)あつたが, 一般には低下するも のが過半数に認められた. Tagnon ら (1953) が発情物 質の術前投与は外科的手術の出血を減少させると発表. Goodhope (1960)も臨床的に認めている. だ゙Goodhope は polyestradiol phosphate を投与した場合の 量は40 $\mathrm{mg}$ が適当で，それ以上ではかえつて出血傾向を助長する 傾向もあるらしいという．とのととは上記した著者の実 験成績 (hexestrol 投与量の多いもので protease の増 加があつた）とも一致する.

前立腺癌組織内 $\bigcirc$ protease む個人差を示し，最高23.4 単位最少 5.2 単位であるが, 大体において10.0単位前後 の含有量と見ることができる(第 5 表).また，ての含有量 は病理組織像とはとくに関連はない。括そらく酸 P-ase と同じょうに, protease含有量もむしろ癌細胞心多眎に よるものとも考えられる.いずれにしろ, pratease 含有 量については前立腺癌組織と前立腺肥大症(腺腫)組織と の間に葟とんど差異はないと考えてよい，ところが，予 め発情物質を投与した後に切除採取した前立腺癌組織で は，そのprotease含有量は明かになり強く抑制されてお り，乙の抑制現象も前立腺肥大症の場合よりはるかに顕 著である(第 4 表, 第 5 表).とれと発情物質による癌細胞 の形態的変化さは必ずしも一致せず，むしろ軽度ながら 形態的変化を認めたもので protease の抑制が少ないも のもあるという現象が認められている．同様のとと注剔 除術を行なつた第 6 表, 第 2 例でも認められる. しかし前 立腺癌に执いても proteaseを指標とした場合, 酸 P-ase とほぶ同様にやはり発情物質によつてその座生能がょり 強く抑制されると考えてよい。

以上飞記述したとこらから，酢素学的に前立腺肥大症 と前立腺澏のホルモン依存性というものに梳明かにちが いのあることが磼められたといえる。すなわち， protease は一応別として前立腺肥大症も前立腺癌もその産生 機能が男性ホルモンの支配下にある酸 P-aseから見た場 合は、同じように男性ホルモン依存性をもつということ ができるが，発情物質に対する感受性という観点からは 自律性発育を特徵とする前立腺癌の方がこのホルモンの 影響をうけやすく，良性腫瘍たる前立腺肥大症はかえつ 
てホルモンでコントロールをなし難いといろ著しい差異 を示しているわけである。つまり，前立腺肥大症ははつ きりとホルモン依存性腫痬とはいえないものである.

Huggins（1960）はホルモン依存性腫瘍というものを 次のように定義している. 瘦というもの注すべてが全く 自律性(autonomous)だとはがらない.ある組織の細跑 の代謝活動が強くあるホルモンに依存している場合，そ の組織を発生母地とする癌細胞も同じょうにホルモンに 依存して抢り，正常細胞と同様にもしとのホルモン供給 がなくなるこ癌細胞も萎縮する．とのような癌をホルモ ン依存性癌と定義するというのである．乙の前立腺癌が ホルモン依存性癌であること，乙れに対し前立腺肥大症 の方は本来の意味でこのホルモン依存性腫湯というもの には入れ難いものであるととを, 従来専ら定性的あるい は形態的な面から検索されていたのに対し，上に記述し た著者の臨床笂験成績认前立腺組織そのものについて定 量的あるいは酵素学的にこれを裏づけ得たものである。

\section{V. 結 語}

(1) 著者注前立腺肥大症 (腺腫) 怙よび前立腺癌 ホルモンとの関係，とくに後者のホルモン依存性癌とい ろことにつき, 主として機能の面から生化学的醳素学 的に検索する目的で, 前立腺乙密接な関係をもつ phosphatase (主として酸 phosphatase) 扮よび同じくある 程度の関連性が推定されている protease という酥素の 活性度を指標して, 正常前立腺 (4 例) 前立腺腺腫 (39 例),前立腺癌 (20例) の組織抽出液にこれら䤃素の組織 内含有量定測定するとともに，いわゆる抗男性ホルモン 療法（発情物質投与あるいは除睪術）による醭素含有星 の消長をも定量的に追求比輘した. 組織抽出液の酸phosphatase (P-ase) アルカリP-ase抢よび protease 汸て れぞれ Fishman-Ler-ner法を原理とする Hudson 法, Bessey-Lowry 法, Casein-Folin 法（萩原）によつた。 その結果以下のょうな成績を得た。

（2）正常前立腺組織 $1 \mathrm{~g}$ 当りの酸 P-ase含有量注0. 16〜0.18単位とほぶ一定した值を示していた。

(3) 前立腺腺腫組織 $1 \mathrm{~g}$ 当りの酸 P-ase含有量牥, 一般に正常前立腺のそれょりも明か认高い含有量を示し ている．個くの例ではある程度の差異を示して抢り，乙 れは腺腫の組織像と関係していると考えられるもので, 腺管構造のよく発達したもので 1.0 単位前後, 間質組 織の占める割合が大きくなるにしたがつて 0.4単位から 0.2単位前後の值であつた。予め発情物質 (hexestrol) を投与してから剔除した前立腺腺腫組織の酸 P-ase含有 量は hexestrol 100mg投与で法とんど減少せず，200
〜 300mg以上でも極めて軽度にしか減少しない.いずれ の場合も組織学的には hexertrol 投与による形態的変化 は発生していない。

(4) 前立腺癌組織 $1 \mathrm{~g}$ 当りの酸 P-ase含有量は, 組 織学的に分化した腺癌か未分化癌かには活とんご関係な く, 大部分は $0.4 \sim 1.0$ 単位の值を示した. これ沈前立 腺腺腫と添とんぞ同じて，正常前立腺のそれより注明ら 䒕に高値であつた. 予め発情物質を投与した（あるい注 少数例では除睪術) 後に切除採取した前立腺癌組織の酸

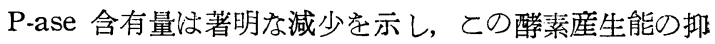
制は $100 \mathrm{mg}$ 以上の発情物質投与ですでに明かに確認され 心. 発情物質投与による組織学的变化は 3 例にごく軽度 に認めら行た程度であつた。すなわち組織内酸 P-aseの 量的消長示ら, 前立腺癌牥多量の酸 P-ase它もつととで は前立腺肥大症と同じといえるが, 後者と著しく異ると ころ注抗男性ホルモン療法に極めて鋭敏に反応すること て, ての機能的变化は形態的変化が発生するのに先立つ て現われてくる. との成績は前立腺癌は前立腺肥大症と らがい, その発育增殖がホルモンによつてコントロール

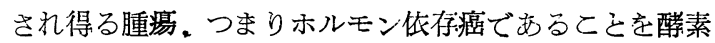
学的に裏づけるデータである.

（5）アルカリP-aseは著者凹測定法（前立腺組織抽 出液の 50,000 倍稀釈液での測定) では正常前立腺, 前立 腺肥大症拉よび前立腺癌組織のいずれでも定量できなか つた.つまり前立腺は正常, 腫瘍を問わず組織内のアル カリ P-aseは含有されていても, P-ase 酸のように特異 的といえるほど多量に含まれているものではない。

（6） Protease の組織内含有量はかなりの個人差が あるが，一般的にいつて正常前立腺，前立腺肥大症掠よ び前立腺癌の值は大体に掞いて 5.0 10.0単位で前者と 後者との間には酸 P-aseの場合のようなちがいは認めら れなかつた。予め発情物質を投与した後の組織内 protease 含有量は非投与にくらべ前立腺腺腫でも前立腺癌 でも明办に減少して招り，乙の減少度は前立腺癌の方に や>著明であつた. しかし, $100 \mathrm{mg}$ 以上投与例のうち少 数例ではかえつて高値をした。

\section{交献}

1) Abdl-Fadl, M.A.M. , and King, E.J.: Biochem. J. 45, 51, 1949.

2）馬場：日泌尿会誌, 50, 1113, 1959.

3) Babson, A.L., Read, P.A., and Phillips, G.E.: Am. J. Clin. Path. 32, 83, 1959.

4) Bessey, O.A., Lowry, O.H., and Brock, M.J.: J. Biol. Chem. 164, 321, 1946.

5) Brendler, H.: Cooperative !Study Program 
in Therapy of Advanced Prostatic Cancer. Biological Activities of Steroids in Relation to Cancer ed by G Pincus \& E.P. Vollmer, P 401, Acad. Press, New York, 1960.

6) Downey, et al.: Brit. J. Urol. 26, 160, 1954.

7) Fishman, W.H., Bonner, C.D., and Homburger, F.: New Engl. J. Med. 255, 925, 1956.

8) Fishman, W.H., and Lerner, F. : Biol. Chem. $200,89,1953$.

9) Goctsch, J.B.: J. Urol, 84, 636, 1960.

10) Goodhope, C.D.: J. Urol. 84, 386, 1960.

11) Gutman, A.B., and Gutman, E.B.: Proc. Soc. Exper, Biol \& Med. 38, 470, 1938.

12) Gutman, A.B., and Gutman, E.B.: J. Clin. Invest. 17, 473，1938

13) 荻原：酵素研究法, 朝倉書店, II : 240 , 昭36。

14) Hudson, P.B., Brendler, H., and Scott, W.W.: J. Urol. 58, 89, 1947

15) Hudson, P.B., Finkle, A.L., Hopkins, J.A., Sproul, E.E., and Srout, A.P.: Cancer 7, $690,1954$.

16) Huggins, C.: Steroids, Growth and Cancer. Biological Activities of Steroids in Relation to Cancer ed by G Pincus \& E.P. Vollmer, P. 1, Acad. Press. New York, 1960.

17) Huggins, C., and Clark, P.J.: Exper. Med. $72,747,1940$.

18) Huggins, C., and Hodges, C.V.: Cancer Res. 1, 293, 1941.

19) Huggins, C., and Neal, W.: J. Exper. Med. $76,527,1942$.

20) Huggins, C., and Scott, W.W.: Ann. Surg. 122, 1031, 1945.

21) Huggins, C., and Talalay, P.: J. Biol. Chem. 159, 399, 1945.

22）糸井：日泌尿会誌，50，597, 1959.

23）金井.：臨床検查法提要，金原出版，VII-71, 昭 36 .

24) Kirk, J.E., Wang, I.C., and Schans, R.: J.
Lab. Clin. Med. 57, 705, 1962.

25) 黒田: 日本泌尿器科全書, 金原- 南江堂, 7, $169,1957$.

26）黒田, 久住, 向来：日泌尿会誌，53，735, 1962 .

27) Ladehoff, A.A., and Rasmussen, J.: Scandinav. J. Clin. Investigation 13, 231, 1961.

28) Lombardo, L.J.: J. Internat. Coll. Surgeons $30,412,1958$.

29) Lombardo, L.J.: J.A.M.A. 169, 1718, 1959.

30) Mann, T.: The Biochemistry of Semen, Methuen \& Co., Lonłon, 1954.

31) Marberger, H., Riedsel, R.D., Anderson, D.O., and Malek, L.H.: J. Urol. 75, 857, 1956.

32）松本：日泌尿会誌，52，72，1961.

33) 松村：日泌尿会誌, 50, 902, 1959 .

34) 落合：日本臨床, 18, 2497, 1960.

35) 落合：臨床酵素学, 朝倉書店, 247, 1963.

36) Prout, G.R., Siegel, M., and Cliffton, E.E.: J.A.M.A. 160, 840, 1956.

37) Seligman, A.M., Chauncey, H.H., Nachlas, M.M., Manheimer, L.H., and Ravin, H.A. J. Biol. Chem. 190, 7, 1951.

38) Shelley, H.S., Auerbach, S.H., Classen, K.L., Marks, C.H., and Wiederanders, R.E.: A.M. A. Arch. Surg. 77, 751, 1958.

39) Shinowara, G.Y., Jones. L.M., and Reinhart, H.L.: J. Biol. Chem. 142, 921, 1942.

40) Tagnon, H.J., and Steens-Lievens, A.: Cancer 13, 507, 1960.

41) Tagnon, H.J., Whitmore, W.F., and Shulman, N.R.: Cancer 5, 9, 1952.

42) Tagnon, H.J., Whitmore, W.F., Shulman, P., and Kravitz, S.C.: Cancer 6, 63, 1953.

43) 竹内：ホルモンと臨床, 11, 176, 1964.

44) Woodard, H.Q.: J. Urol. 65, 688, 1951.

45) Woodard, H.Q.: Cancer 5, 236, 1952. (昭和39年 3 月 15 日受付) 